Proc. Estonian Acad. Sci. Geol., 1991, 40, N 2, 61-68

Antanas BRAZAUSKAS* and Petras MUSTEIKIS*

\title{
BRACHIOPOD AND CONODONT DISTRIBUTION AT THE WENLOCK-LUDLOW BOUNDARY OF LITHUANIA
}

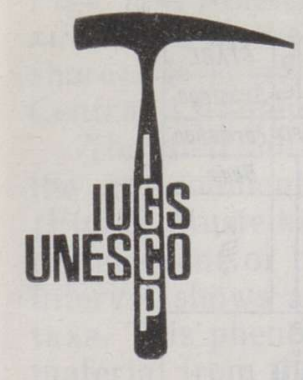

GLOBAL BIOEVENTS

The aim of our investigations was to elucidate the influence of environmental changes in the Wenlock-Ludlow boundary interval on brachiopod and conodont distribution. For this purpose cores of 24 boreholes from all facies zones of Lithuanian Silurian (Fig. 1) were examined. The vertical distribution of brachiopods and conodonts was evaluated with respect to the corresponding lithostratigraphical subdivisions of graptolite and conodont zones (Пашкевичюс, 1979; Бразаускас, 1987). Also, brachiopod and conodont communities were distinguished and their distribution at this boundary was investigated.

Among brachiopods one really significant taxonomic change was established in the studied interval

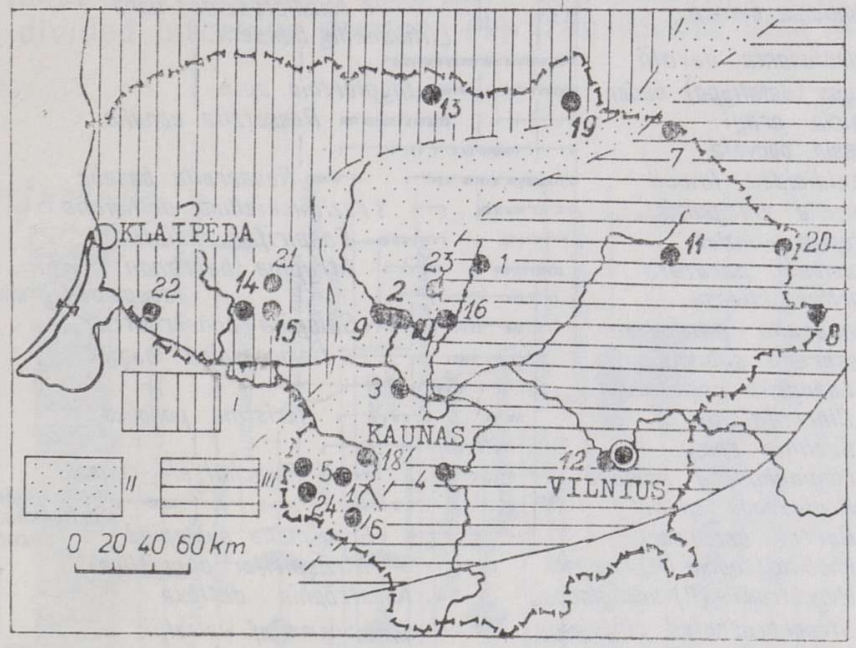

Fig. 1. Location of the boreholes studied. I - clayey and clayey-carbonaceous Silurian facies, II - intermediate zone between clayey and carbonaceous facies, III - carbonaceous facies. Boreholes: 1 - Krekenava-7; 2 - Geluva-99; 3 - Sutkai-87; 4 - Prienai-3; 5 - Virbalis-5; 6 - Kalvarija-2; 7 - Butkūnai-241; 8 - Tverečius-336; 9 Gèluva-114; 10 Gèluva-115; 11 - Svedasai-252;12 - Jačionys-299; 13 - Kriūkai-146; 14 - Tauragè-11; 15 - Pašaltuonis-94; 16 - Graužai-105; 17 - Vilkaviškis-129; 18 - Pilviškiai-141; 19 - Parovèja-9; 20 - Drūkšiai-324; 21 - Viduklè-61; 22 - Stoniškiai-1P; 23 - Ledai-179; 24 - Pajavonys-13.

* Geologijos ir mineralogijos katedra Vilniaus universitetas (Department of Geology and Mineralogy, University of Vilnius), Ciurlionio 21/27, 232000 Vilnius, Lithuania. 


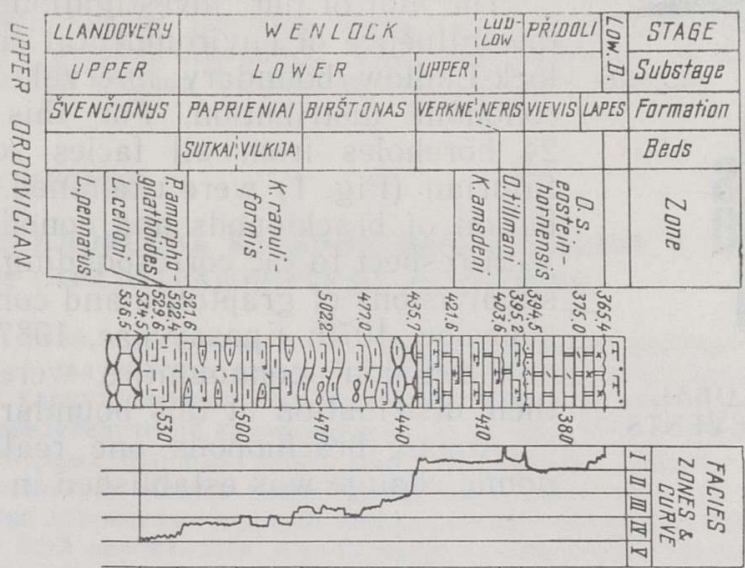

Pentlandella tenuistriata Dicoelosia baltica

Eoplectodanta duvalii Atrypa (Gatatrypa) hedei Aegiria grayi Glassia abavata Skenidioides lewisii Visbyella visbyensis Atrypidae indet. Dicaelosia paratata Isarthis clivasa Mendacella parva Resserella sabrinae Leangella segmentum "Clarinda" sp. Coolinia sp.sp. Plagiarhyncha analaga Protozeuga sp. $n$. Cyrtia. exparrecta Pholidastrophia (M.) laevigata Megastrophia (P.) semiglabosa Straphochonetes cingulatus Leptaena cf. depressa Nucleaspira pisum. Atrypa reticularis Dnniella pashkevichiusi Resserella? sawddensis Dicoelosia bilaba Dalejïna hybrida Streptis grayii Dalerarthis rustica
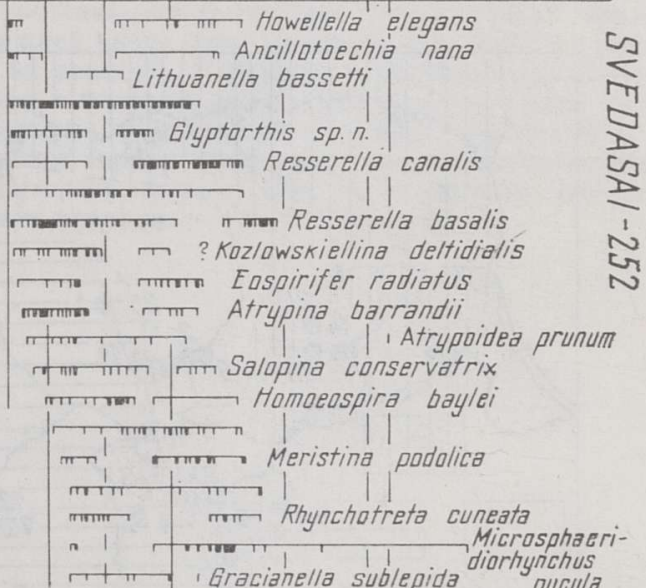

r I Gracianella sublepida diarnynehus

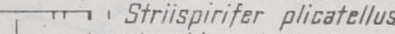

n Anastrophia deflexa
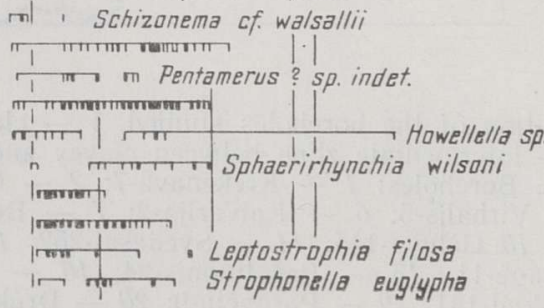

Fig. 2. Distribution of brachiopods in the Silurian of the Svedasai-252 borehole (lithological legend see in Fig. 4). 
and it was proved diachronous and environmentally controlled (Musteikis, in press). In East Lithuania this change started in the upper part of $K$. ranuliformis ( $M$. flexilis) Zone while westward close to Central Lithuania it happened at the $G$. nassa-M. ludensis ( $O$. siluricus) level (boreholes Butkūnai-241, Svedasai-252, Tverečius-336, Krekenava-7, Graužai-105; see Figs. 1, 2; Мустейкис, 1989; Musteikis, in press). In Central Lithuania this change was at the $M$. ludensis- $N$. nilssoni $(O$. bohemica) level (boreholes Geluva-99, Sutkai-87, Vilkaviškis-129, Pilviškiai-141 and others, see Figs. 1, 3; Musteikis, in press; Мустейкис, 1989; in press). In West Lithuania the same brachiopod taxonomic change started at the $N$. nilssoni-

$L$. progenitor and ended at the $M$. tauragensis level in westernmost Lithuania (boreholes Kriūkai-146, Pašaltuonis-94, Vidukle-61; see Figs. 1, 4; Musteikis, in press). So, this diachrony ranges from the M. Plexilis Zone in the east (onshore) to $M$. tauragensis Zone in the west (offshore). It coincides in time with the Wenlock-Ludlow boundary only in Central Lithuania.

The distribution of brachiopod communities is also diachronous along the environmental gradient and follows the general basin regression (Fig. 5; Musteikis, in press; Мустейкис, 1985). The analysis of the vertical replacement of brachiopod communities in the Wenlock-Ludlow boundary interval shows a decrease in their diversity and the relative abundance of taxa. This phenomenon is related with the increased supply of terrigenous material from the west (Scandinavia) at this time (Лапинскас, 1987; Musteikis, in press). It suppressed normal carbonate sedimentation in the central part of the basin and caused higher water turbidity, i. e. brought about restrictive factors for brachiopod distribution. For the descriptions of communities shown in Fig. 5 see (Musteikis, in press; Musteikis and Paškevičius, in press; Мустейкис, 1989; in press).

Conodont distribution at the Wenlock-Ludlow boundary is of a similar pattern. About thirty conodont taxa have been established at this boundary. They are divided into four groups: (1) transitional taxa which appeared

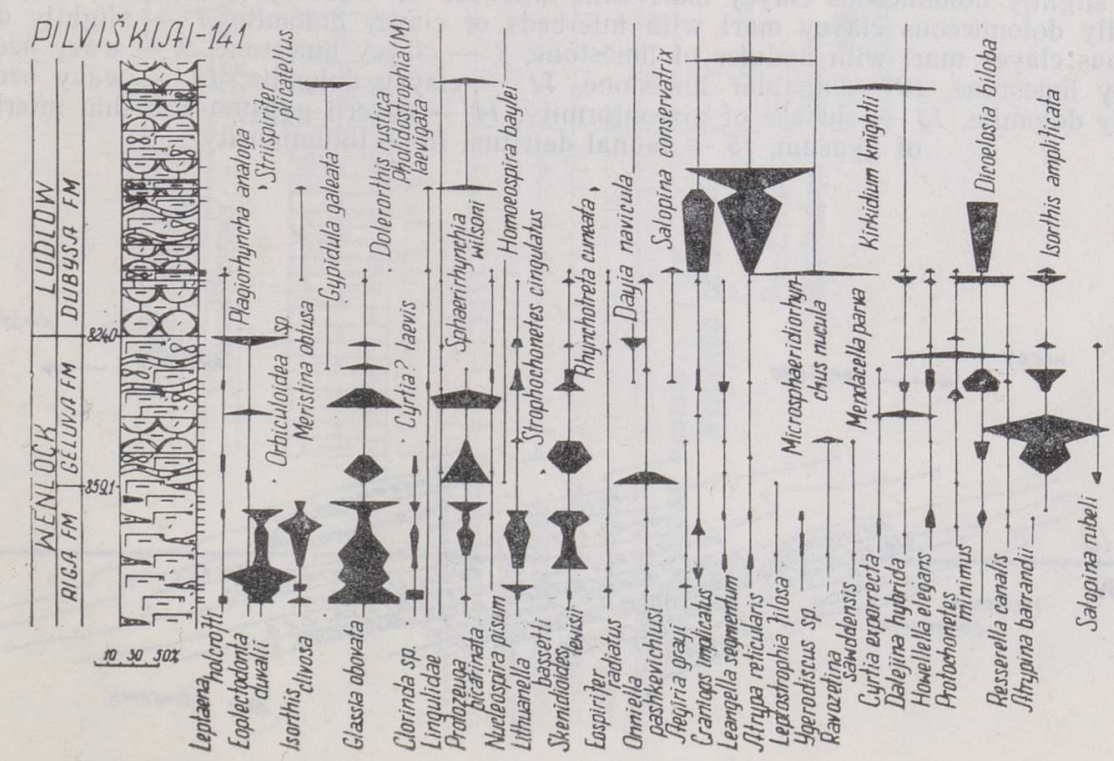

Fig. 3. Distribution and percentages of brachiopods at the Wenlock-Ludlow boundary of Pilviškiai-141 borehole. 


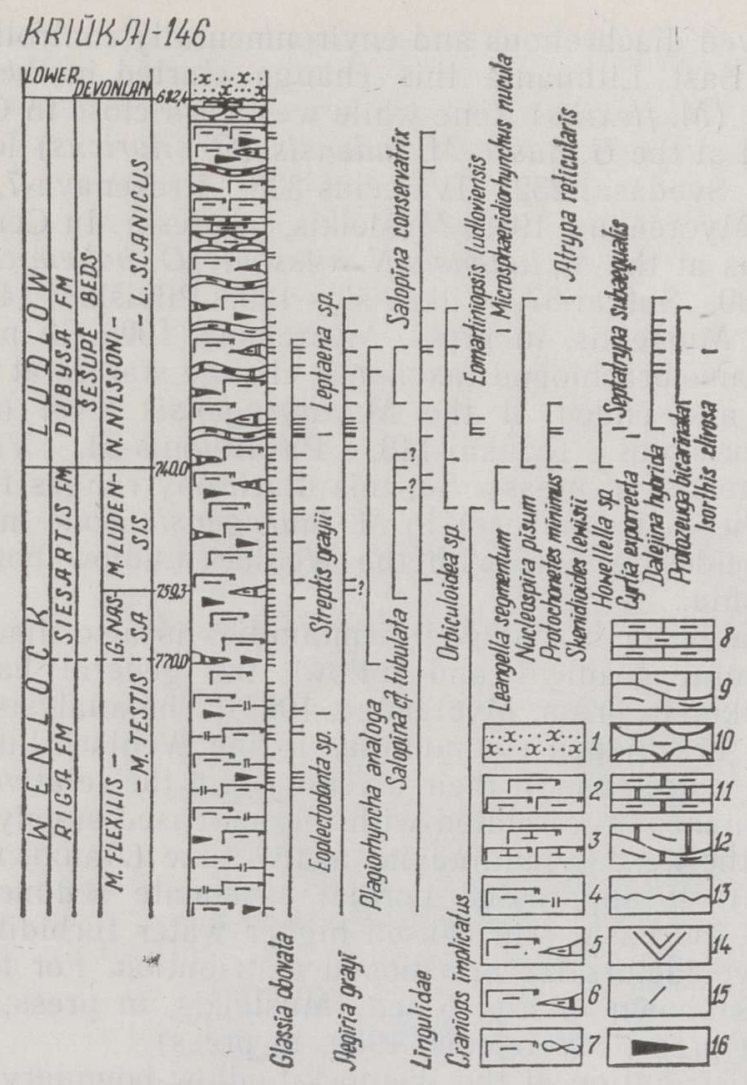

Fig. 4. Distribution of brachiopods at the Wenlock-Ludlow boundary of Kriūkai-146 borehole: 1 - sandstone, 2 - slightly dolomiceous clayey marl, 3 - dolomitic clayey marl, 4 - slightly dolomiceous clayey marl with interbeds of slightly dolomiceous clay, 5 - slightly dolomiceous clayey marl with interbeds of microcrystalline limestone, $6-$ slightly dolomiceous clayey marl with interbeds of clayey dolomite, 7 - slightly dolomiceous clayey marl with nodules of limestone, 8 - clayey limestone, 9 - wavy bedded clayey limestone, 10 - nodular limestone, 11 - clayey dolomite, 12 - wavy bedded clayey dolomite, 13 - surface of disconformity, 14 - cavern gypsum and thin interbeds of gypsum, 15 - faunal detritus, 16 - bituminosity.

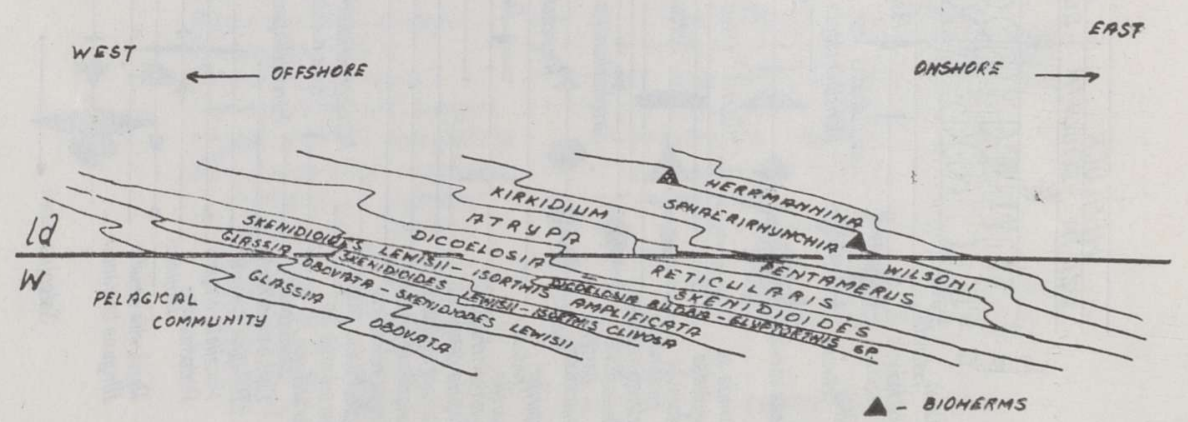

Fig. 5. Generalized sketch of the distribution of brachiopod communities at the WenlockLudlow boundary along the environmental gradient. 
in the early Wenlock and disappeared in the late Ludlow or later; (2) taxa which occurred only in the Wenlock; (3) taxa which occurred only in the Ludlow, and (4) index-taxa of conodont zones. Conodont zonation has made possible a more exact correlation of clayey and carbonaceous facies and also a better substantiation of the Wenlock-Ludlow boundary in the whole basin. It also enabled to establish a big hiatus in East Lithuania (Бразаускас, 1987).

The distribution of transitional conodont taxa is environmentally controlled, i. e. their appearance and disappearance is correlated with the overall basin regression. For example, Panderodus gracilis (Branson et Mehl) appeared in East and Central Lithuania in the early Wenlock (Figs. 6, 7; Бразаускас, 1987), and in West Lithuania only in the Ludlow (Бразаускас, 1987). Ozarkodina densidentata (Viira) appeared in the $K$. ranuliformis Zone (early Wenlock) in East Lithuania (Fig. 6), in the O. siluricus Zone close to Central Lithuania (Fig. 7), in the O. bohemica Zone in Central Lithuania (Fig. 8), and in the K. variabilis Zone (early Ludlow) in West Lithuania (Vidukle-61 borehole, Fig. 1; Бразаускас, 1987).

Environmental control was obvious also in the abundance of conodont taxa (Figs. 6,7). This control is mostly expressed in ratio fluctuations of blade and simple cone conodont abundances: onshore blade conodonts

\section{BUTKŪNAI - 241}

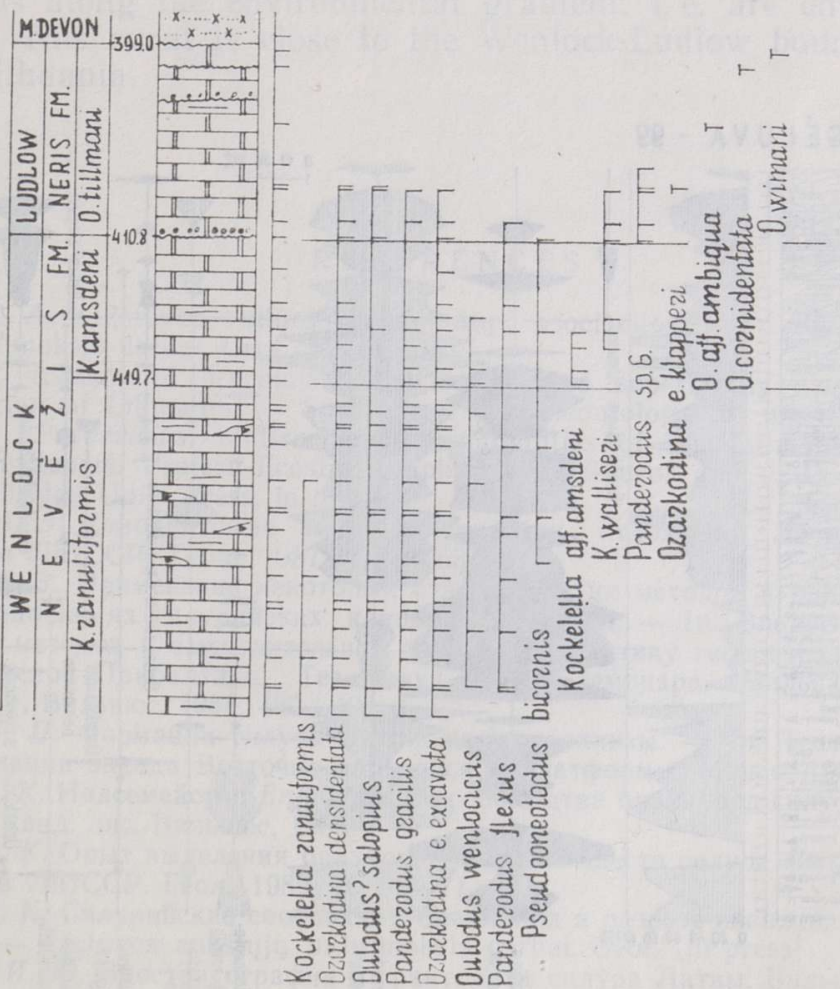

Fig. 6. Distribution of conodonts at the Wenlock-Ludlow boundary of Butkūnai-241 borehole. 


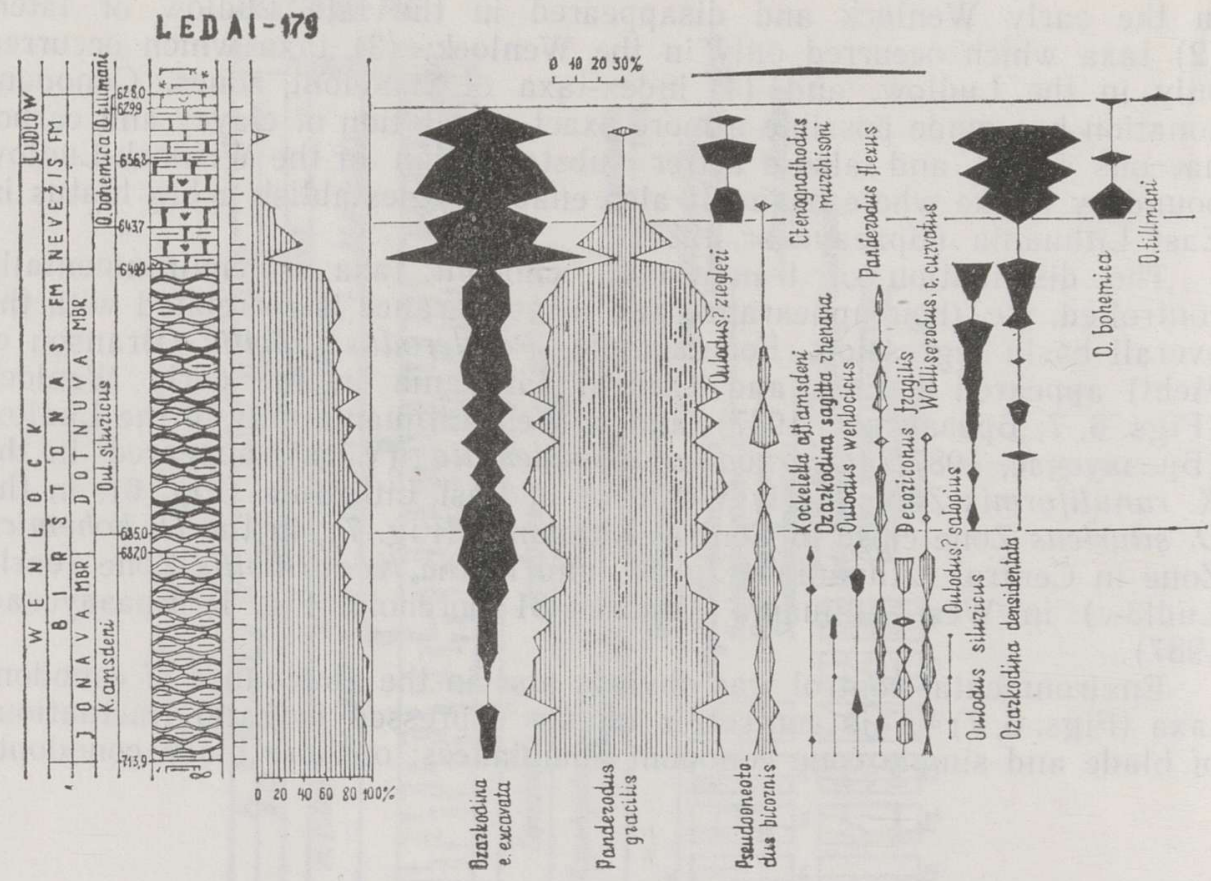

Fig. 7. Distribution and percentages of conodonts at the Wenlock-Ludlow boundary of Ledai-179 borehole.

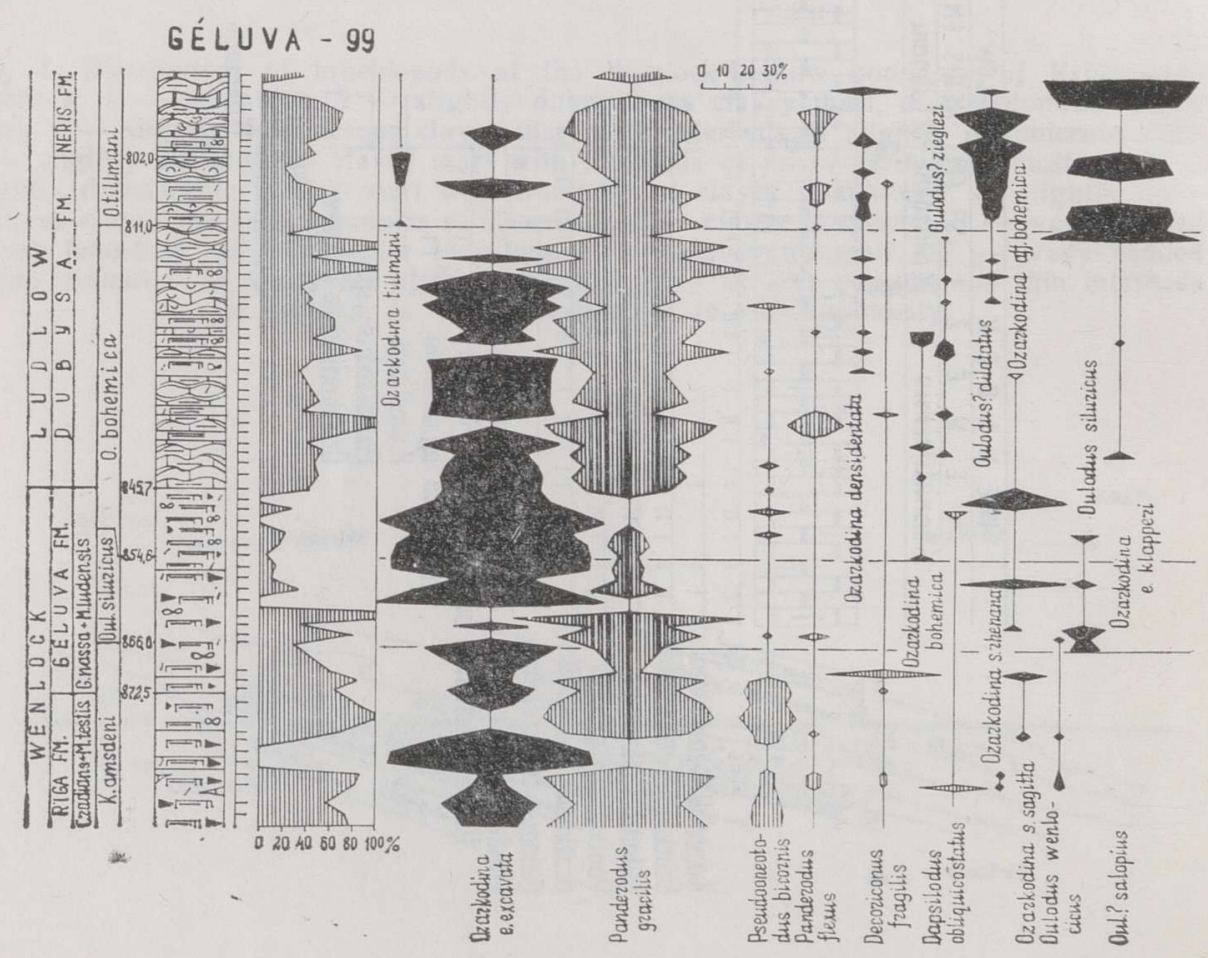

Fig. 8. Distribution and percentages of conodonts at the Wenlock-Ludlow boundary of Gèluva-99 borehole, 


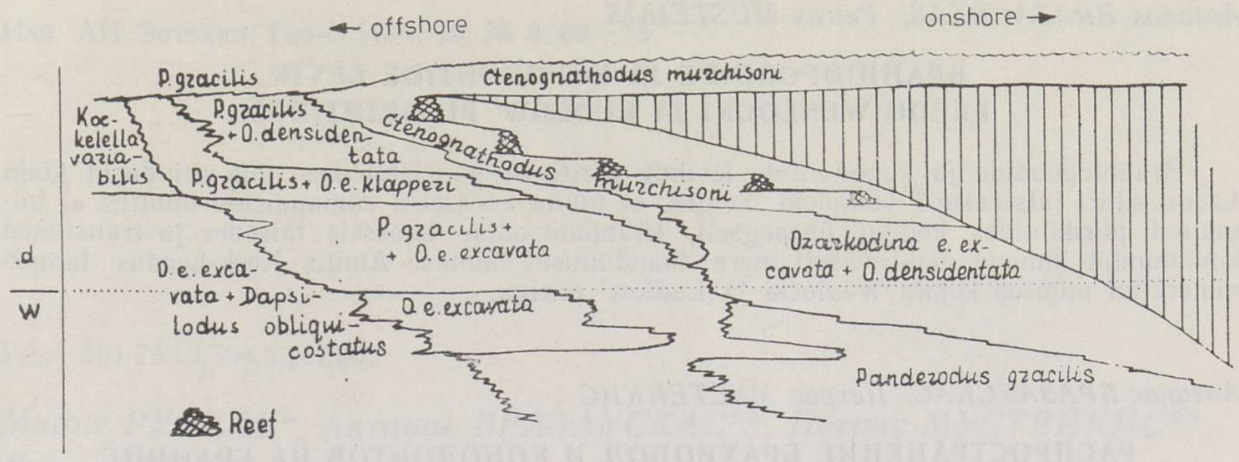

Fig. 9. Generalized sketch of conodont associations distribution at the Wenlock-Ludlow boundary along the environmental gradient.

prevail and offshore simple ione conodonts prevail. The vertical replacement of conodont associations was diachronous along the environmental gradient in the Silurian basin of Lithuania and it reflects its general regression at that time (Fig. 9) (Brazauskas, in press; Бразаускас, 1988).

Following the conclusions made above we can say that the change of brachiopod and conodont faunas near the Wenlock-Ludlow boundary was not an isochronous event. The most significant taxonomic change of brachiopod fauna and appearance of transitional conodont fauna are diachronous along the environmental gradient, i. e. are environmentally controlled. This event is close to the Wenlock-Ludlow boundary only in Central Lithuania.

\section{REFERENCES}

Brazauskas, A. Lietuvos silüro konodontų asociacijos. - Lietuvos aukštuju m-lu mokslo darbai. Geol., 12, in press.

Musteikis, P. Aspects of brachiopod distribution and superfamily Enteletacea in the Silurian of Lithuania. - Spec. paper in Paleontology, in press.

Musteikis, P., Paškevičius, J. Brachiopod communities of the Lithuanian Silurian. Final Report. Project Ecostratigraphy. A. J. Boucot and J. D. Lawson (eds.). Cambridge Univ. Press, in press.

Бразаускас А. З. Конодонтовые зоны силурийских отложений Литвы. - Науч. тр. вузов ЛитССР. Геол., $1987,8,40-58$.

Бразаускас А. З. Применение неқоторых статистических методов в палеоэкологических исследованиях силурийских конодонтов Литвы. - In: Внедрение математических методов и вычислительной техники в практику геологоразведочных работ Советской Прибалтики. Тез. науч.-практ. семинара, Вильнюс, 23-24 июня 1988 г. Вильнюс, 1988, 189-191.

Лапинскас П. П. Формации силура Балтийской синеклизы. - In: Тектоника, фации и формации запада Восточно-Европейской платформы. Минск, 1987, 103-116.

Мустейкис П. K. Надсемейство Enteletacea и сообщества брахиопод силура Литвы. Автореф. канд. дис. Вильнюс, 1985.

Мустейкис П. К. Опыт выделения брахиоподовых сообществ силура Литвы. - Науч. тр. вузов ЛитССР. Геол., $1989,10,52-71$.

Мустейкис П. К. Силурийские сообщества брахиопод в разрезе скважины Вилкавишкис129. - Lietuvos aukštujų m-lų mokslo darbai. Geol. (in press).

Пашкевичюс И. Ю. Биостратиграфия и граптолиты силура Литвы. Вильнюс, 1979.

Presented by D. Kaljo

Received

Nov. 20,1990 


\section{BRAHHIOPOODIDE JA KONODONTIDE LEVIK LEEDU WENLOCKI JA LUDLOW' PIIRIKIHTIDES}

Brahhiopoodide ja konodontide levikut uuriti 24 puurläbilõikes, mis esindasid kõiki Leedu siluri fatsiaalseid vööndeid. Selgus, et fauna koosseisu silmapaistev muutus ei toimunud piirikihtides kōikjal üheaegselt. Brahhiopoodide koosseis teisenes ja transiitsed konodondid ilmusid diakroonselt mere taandumise suunas. Ainult Kesk-Leedus langes nimetatud muutus kokku Wenlocki ja Ludlow' piiriga.

Антанас БРАЗАУСКАС, Петрас МУСТЕЙКИС

\section{РАСПРОСТРАНЕНИЕ БРАХИОПОД И КОНОДОНТОВ НА ГРАНИЦЕ ВЕНЛОКА И ЛУДЛОВА ЛИТВЫ}

Изучено распространение брахиопод и конодонтов в интервале перехода от венлока к лудлову по разрезам 24 скважин из всех фациальных зон силура Литвы. Установлено, что существенное обновление фаунистического состава не было одновременным. Самая значительная смена брахиоподовой фауны и уровни появления транзитной фауны конодонтов происходили диахронно вдоль градиента среды, т. е. следовали общей регрессии бассейна. Только в Средней Литве это событие происходило на границе венлока и луд. лова, 